\title{
Pluralist Albania- Religious Tolerance or Peaceful Coexistence?
}

\author{
Renata Tokrri \\ PhD, Lecturer, University "Aleksandër Moisiu", \\ Durrës, Albania
}

\begin{abstract}
It has been noted that the whole history of man has been marked by religion, in particular the Albanian one by three religions and four religious denominations: the Sunni one, to which the majority of the population belongs, the Bektashi Sufis, which is a very moderate branch of the Islam, the Orthodox and Catholics. Over the centuries, Albania has become a multireligious society, but what is singular is that despite profound differences in religion the Albanians have always lived together in peace, the country has never known extremism, conflict or war of religion. Several authors have tried to identify the source and reasons for this exemplary harmonious coexistence that still reigns in the country, but the real reason is still a matter of dispute among intellectuals. It is certainly the answers can only be found in history.
\end{abstract}

Keywords: religious tolerance, religious coexistence, religious pluralism, the principle of secularity of the state.

\section{Introduction}

As regards the religious adhesion of the Albanians we do not have an exact percentage, since the 2011 census, in which citizens were asked, if they wanted to, to indicate their religion, cannot be considered a reliable source, as a a large part refrained from answering this question and the orthodox minorities boycotted it.

Some authors believe that this census is unconstitutional in the parts in where it plans to express its religious or ethnic belonging. (P. Xhufi, 2011; see., G. Bregasi, 2011).

However, the result showed that Sunni Muslims make up about 57 percent of the population, Catholics 10 percent, Orthodox Christians about 7 percent and Bektashi 2 percent. Further groups are Baha'is, Jehovah's Witnesses, The Church of Jesus Christ of Latter-day Saints (Mormons). As can be understood, the abstention was such as to subvert a constant statistic and indicate Catholics as majorities compared to the Orthodox. This demonstrates the absolutely relaxed and equidistant attitude of 
Albanians towards religious denominations. Confirming this, the state's recognition of the Jewish religion in the same year.

It is noted that "Catholics, although the least numerous, represent the first religion of Albanians, they are still the only bridge connecting Albania with Europe. Muslims, although it is the youngest religion in Albania, have the same legitimacy. Assured, not only by their large presence, but also by their significant contribution on the Albanian people's path towards freedom and emancipation. Albanian Orthodox, as well as Catholics, as well as Muslims, have been an inseparable part of the national body. This balance and legitimacy are a reality, they are the essence. Albania is a country with three religions, but it cannot be identified with any of them "(I. Kadare, 2003).

\section{Pluralist Albania yesterday}

Although multireligiousness has always characterized Albania, the country has never known religious clashes, which is very particular, as Kadare also points out, "in an area famous for its quarrels and grudges. A people that is not at all calm, indeed I would say tending, like the great majority of the Balkans, to irritation" (I. Kadare, 2003).

For this reason, scholars have tried to find the reasons for this admirable cohabitation. But what is the real reason for this exemplary coexistence is still a matter of dispute among intellectuals, some are looking for the reason in the almost half century of antireligious communist atheism, others in the so-called Albanism, still others on the imposed faith (A. POPOVIC, 1986).

With regard to the communist regime, Belgiorno de Stefano compares and highlights that, "just as international conventions to protect human rights were born from the horrors of the Second World War, so Albanian religious peace was born from the madness of the Albanian communist atheocracy, a model for the whole world". (M. G. BELGIORNO DE STEFANO, 2014).

Undoubtedly the communist regime has influenced further, but it was not a determining factor, as peaceful coexistence existed before the advent of the old regime.

Another detail, shared by all scholars, is that a kind of lack of devotion has been found in the Albanians, even among the faithful ones. In fact, Muslims were not devoted to Islamic doctrine, on the other hand even medieval Christianity is characterized by its popular and non-dogmatic traits, and the rites were often mixed with traditional customs. Some believed, that this lack of devotion to the ideas of the Holy Scriptures or the Koran was the result of a lack of education of the religious who had to transmit religious dogmas.

The situation of the religious phenomenon after the fall of the atheist regime can be grasped in the words of Pegues who writes that "when a missionary in the country asks an Albanian a question about Jesus, the man replied:" I love Jesus. I am a Muslim ". Pushed to clarify, the man replied that his father's family was Christian, instead of his 
Muslim mother. For him, there was no further consideration of the meaning of faith "(B. J. PEGUES, 2007).

In this way, religion was built around its own traditions and customs by generating points of contact between all beliefs, consequently in the other one recognized traits of one's own life. In fact, all this mixing, certainly together with other elements, has led to the absence of religious fanaticism.

On the other hand, even those differences that were found were mitigated by the desire for dignity and national freedom that in the vision of the Albanians could only be achieved if united, thus tempering any religious diversity and generating the socalled Albanian religion, i.e. the so-called albanism. Surroi believes that "being born Albanian, in broad terms, means being born tolerant of religious diversity (...) The reasons for this tolerance lie in the fact that, unlike its neighbors, the Albanian nation is not built by a religion and / or around to a religion. Furthermore, the road to building the nation has been longer, even more difficult, because it has also implied internal pluralism ". (V. SURROI, 2004).

Without a doubt religion has always been in the background, and the sense of the homeland of the traditions of language and folk have prevailed over the religious one.

During the Albanian Renaissance, the principle of Albanianity, as the only religion of the Albanians, constituted another prodromal element for the religious tolerance that would have characterized it in the centuries to follow. It was a force of ideologies that infused in the shqipëtarë the spirit of coexistence and the value of diversity. Cimbalo notes that in addition to historical coexistence, the modern process of secularization of the country "has among its strengths not so much the effects, albeit present, of the atheist campaign of the past regime, as the tumultuous acceptance of the values of consumer society and the profound social disintegration following the mass migration from the country that characterized the last decade of the past century "(G. CIMBALO, 2010).

It is also noted that tolerance and the idea of religious pluralism are not modern concepts in Albanian history, since even the national hero Gjergj Kastrioti known as Scanderbeg, as a sign of respect for all religions, kept both names, both that of Catholic birth, than that attributed by the Porte (A. MESI, 2006). Also, in 1938, King Zog, of Muslim religion, married with a Christian, making it known that he was willing, at a later time, to repeat the ceremony of Catholic rite (M. BORGOGNI, 2007).

Morozza della Rocca reminds us that, even during the Communist period, when atheism was now the official religion, the bell of the Orthodox Church of Tirana "was saved by a Muslim, preserved by a Catholic, who returned it to the Orthodox with the regained religious freedom", he also maintains that Albania's peaceful religious pluralism is a value for the country, for the Balkans and for multi-religious Europe. (R. MOROZZO DELLA ROCCA 2004). 
This climate of extreme "tolerance" was also reflected in political life, in fact in 1920 Fan S. Noli (V. BALA, 1965; FS NOLI, 2002; S. BENAR, 1997) was sent to the League of Nations in Geneva as Head of the Albanian delegation. After his speech, in which he asked for support for his nation, the Indian Prime Minister replied inviting the other countries to support him, because in his opinion, it was rare that a country made up of 70 percent of Muslims sends not only an Orthodox, but a priest, to represent him, that priest in 1924 became Prime Minister of Albania.

From here we can also understand the reason why in 2015 the Albanian government proposed as an ambassador to the Holy See, an intellectual of Muslim religion. The Vatican was strongly against the candidacy, with the only motivation, because it was of Islamic faith (F. NIKOLLI, 2015).

\section{Pluralist Albania today}

Today the multi-religious country has adopted the motto that religious diversity is a quality and must be valued. Fuga highlights that, "Particularly among the younger generations who tend to emigrate and be influenced by the Western media, the tolerance and softness of religious beliefs is more developed. They transmit a highly elastic position to the whole of society towards other religions and consider religious confession simply as a private matter of the individual " (A. FUGA, 2003).

In fact, even in the preamble of the Constitution it says that "We, people of Albania (...) with faith in God and/or in other universal values (...) With an afflatus of tolerance and religious coexistence (...) We deliberate this Constitution".

But, from a strictly legal point of view, there is a contradiction between the concept of tolerance and that of coexistence, as the first is a negative principle, because the need for a vertical relationship, and only the authority or who has power can tolerate. As a consequence, it is legally unable to guarantee equal rights and freedoms, on the other hand, the principle of coexistence implies horizontal relationships, in a perspective where everyone is placed in the same plane, and more respects the constitutional guarantee parameters.

This is why the normative text of the Constitution, which unlike the preamble has legal value and force, in article 3 recalls it as a superprinciple, providing that "human dignity, the principles and fundamental human rights, (...) pluralism, national identity, religious coexistence as well as mutual understanding of minorities, are the foundations of the State that has an obligation to respect and protect them".

Another very important principle, which emerges from this article, is that of pluralism. Here too, we can believe that if tolerance respects diversity, pluralism affirms and guarantees coexistence, thus a principle is born for which ethics is a duty of citizens.

In this context, we can define pluralism in Albania as comprehensive pluralism, the aim of which is to welcome as many opposing opinions and to support their peaceful 
coexistence. Thus "comprehensive pluralism must be willing to accept the norms produced by other conceptions of the good, but only on condition that these norms do not interfere with its unifying project". (M. ROSENFELD, 2000).

For Zanchetta, comprehensive pluralism can be defined as "intelligence and political will, not mental rigidity, ductility of law guarantee comprehensive pluralism, a more advanced form of tolerance" (L. ZANCHETTA, 2001). Thus, we can believe that harmony between different religious communities in Albania is an advanced form of tolerance, that is, inclusive coexistence between different creeds. This civil conversation between the various religious denominations reminds us of Bodin's Colloquium Heptaplomeres in which tolerance and dialogue are the key to multireligious coexistence (A. SUGGI, 2005). This whole situation is inevitably reflected in the juridical norms and in the form of secularism adopted. Thus Albanian secularism can be defined as dialoguing, and appears as an evolved form of secularism.

In fact, today in the era of the wars of religion, Albanian pluri-religious dialogue conduces us to a modern and evolved idea, so we can speak not of tolerance, but of an exemplary coexistence.

Because it is precisely "in the pluralism of beliefs, values and interests, the state and law become secular: law separates itself from moral sentiment; morality ceases to be the privileged source of the juridical, in order to reveal itself as personal sentiment, respecting pluralism". (See G. VISENTINI, 2009).

Also, by a careful reading of art. 3 of the Albanian Constitution, the principle of national identity emerges, it is noted that, the latter strengthens the principle of coexistence, as one of the aspects that most characterizes a nation is the faith.

\section{Conclusions}

Multi-religiosity, for well-known historical reasons, is a fundamental element of the identity of a country, it is found in the roots of the national design and in Albania it has taken on very particular similarities, so called albanism. Furthermore, in this context we find that pluralism and religious coexistence are elements that specify national identity.

Finally, it must be observed a definitely positive fact, that no judgment of the European Court of Human Rights has concerned violations of Albania in the matter of freedom of religion.

In this context, the mosaic of the Albanian spiritual heritage is a strength and not a weakness. The people are aware that they are a nation of Sunnis and Bektshi, of Catholics and Orthodox, and certainly also of non-believers. (Crf. B. OBAMA, 2009). All this is effectively guaranteed by the Albanian Constitution, in particular by the principle of secularism of the state. The latter, as we have highlighted, is an avolved and advanced form of secularism, that reflects the religious coexistence that reigns in the country. 
Without a doubt, religious harmony is the result of centuries of coexistence between the different communities, but also the result of a non-discriminatory legislative policy never based on the principle of tolerance, as the State has not recognized itself in the majority religion therefore he did not need to tolerate other religions.

In this way, beyond religion, and out of it, there were found the elements to build the nationalistic consciousness.

\section{References}

[1] BALA, V., Jeta e Fan S. Nolit, (The life of Fan S. Noli), in Buletin shkencor, Shkodër, 1, 1971.

[2] BELGIORNO DE STEFANO, M. G., La coesistenza delle religioni in Albania. Le religioni in Albania prima e dopo la caduta del comunismo, (The coexistence of religions in Albania. Religions in Albania before and after the fall of communism), in Telematic magazine, (www.statoechiese.it), no. 6/2014 17 February 2014.

[3] BENAR, S., Fan Nolin, siç e kam njohur, (Fan Noli, as I have known him), Dituria, Tirana, 1997.

[4] BORGOGNI, M., Tra continuità e incertezza. Italia e Albania (1914-1939), La strategia politico-militare dell'Italia in Albania fino all'operazione "Oltre Mare Tirana", (Between continuity and uncertainty. Italy and Albania (1914-1939), Italy's political-military strategy in Albania up to the "Oltre Mare Tirana" operation), Milan, Franco Angelli, 2007.

[5] BREGASI, G., Censusi dhe feja e Pashko Vasës, (Census and religion of Pashko Vasa), in www.peshupauje.com, 2011.

[6] BUDA A., Fan S. Noli (1882-1965), in Studia Albanica, 1, 1965.

[7] CIMBALO G., I rapporti tra lo Stato e le Comunità religiose in Albania, (Relations between the state and religious communities in Albania), in Stato, Chiese $e$ pluralismo confessionale, Telematic magazine, (www.statoechiese.it), May 2010.

[8] FUGA, A., Sjellja e Shqiptarëve të sotëm ndaj fesë, (The behavior of today's Albanians towards religion), in Fetë dhe Qytetërimet në Mijëvjecarin e ri -Rasti i Shqipërisë-Konferencë Nderkombëtare, 14-15 November 2003. Ed. Qendra Shqiptare per të Drejtat e Njeriut, Tirana, 2004.

[9] KADARE, I., Fetë dhe Qytetërimet në Mijëvjecarin e ri, (Religions and Civilizations in the New Millennium) in Fetë dhe Qytetërimet në Mijëvjecarin e ri -Rasti i Shqipërisë-Konferencë Nderkombëtare, 14-15 November 2003. Ed. Qendra Shqiptare per të Drejtat e Njeriut, Tirana, 2004. 
[10] MESI A., Religione e spazio pubblico in Albania, (Religion and public space in Albania), in Religioni e Società, 55, 2006, pp. 67-80, Firenze University Press.

[11] MOROZZO DELLA ROCCA, R., Raportet nderfetare në historinë e Shqipërisë: $e$ tashmja dhe e ardhmja, (Interreligious relations in the history of Albania: the present and the future), in Fetë dhe Qytetërimet në Mijëvjecarin e ri-Rasti $i$ Shqipërisë-Konferencë Nderkombëtare, 14-15 November, Ed. Qendra Shqiptare për të Drejtat e Njeriut, Tiranë, 2004.

[12] NIKOLLI, F., George Frendo: Kisha Katolike Kunder Visar Zhitit ne Vatikan, (George Frendo: The Catholic Church Against Visar Zhit in the Vatican), in Gazeta Shqiptare, 7 February 2015, in www.ballkanweb.com.

[13] NOLI, F. S., Autobiografia (Autobiography), Elena Gjika, Tirana, 2002.

[14] OBAMA B., Discorso alla cerimonia di insediamento, (Speech at the inauguration ceremony), 20 January 2009.

[15] PEGUES, B. J., The Persecuted Church Prayer Devotional, Authentic, London, 2007.

[16] POPOVIC, A., L'islam balcanique, Osteuropa Institut, Berlin 1986.

[17] ROSENFELD, M., Interpretazioni - il diritto tra etica e politica, (Interpretations - the law between ethics and politics), Il Mulino, Bologna, 2000.

[18] SUGGI, A., Sovranità e armonia. La tolleranza religiosa nel Colloquium Heptaplomeres, (Sovereignty and harmony. Religious tolerance in the Colloquium Heptaplomeres), Edizione di Storia e Letteratura, Rome, 2005.

[19] SURROI, V., in Fetë dhe Qytetërimet në Mijëvjecarin e ri -Rasti i ShqipërisëKonferencë Nderkombëtare, 14-15 November 2003. Ed. Qendra Shqiptare per te Drejtat e Njeriut, Tirana, 2004.

[20] VISENTINI G., L'etica del diritto è la tolleranza, (The ethics of law is tolerance), in Soc. dir., no.1, 2009.

[21] XHUFI, P., Zeri "kombesi" ne census, antikushtetues, (Voice "nationality" in the census, unconstitutional), www.shqipetariiitalise.com, 2011.

[22] ZANCHETTA, L., Per un nuovo concetto di tolleranza: la politica e il diritto, (For a new concept of tolerance: the politics and law), in Questione giustizia no. 2, 2001. 


\section{Islamic Veil: The Issue of Minors}

\section{Renata Tokrri}

$\mathrm{PhD}$, Lecturer at the University "Aleksandër Moisiu" Durrës-Albania

\section{Abstract}

An important aspect of the Albanian public debate on the exposure of religious symbols concerned minors. In fact, the proposed government law of 2011 was addressed to a category of public school education, that is, regarding students from kindergarten to secondary school. The Islamic veil was always at the center of the debate, but in this case the prohibition was justified as it was aimed at an age group that did not have the ability to make decisions and make choices independently, as in Muslim religion it is expected that a postpubertal girl must wear a headscarf. In fact, in this case the decision-making passes to the parents, who have the right to educate their children according to the dictates of his own conscience. It is stressed that the same circumstance also applies to other religions, where the decision is always made by parents, such as baptism in the Catholic religion. In particular, the Article 24 of the Albanian Constitution, explicitly sanctions the freedom of each person to choose their belief and the prohibition that no one should be forced to participate in the life of a religious community or its practices. The question that arises in this case is whether this constitutional article also protects this category of subjects or only those who have reached the age of majority? The answer is complex and delicate, even to date the Albanian legislator has not remedied it since no one has appealed.

Keyword: Albanian constitution, freedom of religion, religious symbols, Islamic headscarf, the right to educate your own children.

\section{Introduction}

The origin of the veil is lost in the mists of time, a symbol of spirituality, mystery and purity, but also of wealth because in ancient times it was worn by high-ranking women. So also the Muslim religion, not different from the others, has promoted social equality, therefore the veil becomes an economic and imitation symbol.

The veil hides the woman from prying eyes to reveal her only to God and master. In this regard we read in the Koran,

"And say to the believing women (that) they should lower [of] their gaze and they should guard their chastity, and not (to) display their adornment except what is 